\title{
Enhanced antiadhesive properties of chitosan/hyaluronic acid polyelectrolyte multilayers driven by thermal annealing: Low adherence for mammalian cells and selective decrease in adhesion for Gram-positive bacteria
}

\author{
Nicolás E. Muzzio ${ }^{\mathrm{a}}$, Miguel A. Pasquale ${ }^{\mathrm{a}, *}$, Eleftheria Diamanti ${ }^{\mathrm{b}}$, Danijela Gregurec ${ }^{\mathrm{b}}$, Marta Martinez Moro ${ }^{\mathrm{b}}$, \\ Omar Azzaroni ${ }^{\mathrm{a}, *}$, Sergio E. Moya ${ }^{\mathrm{b}, *}$

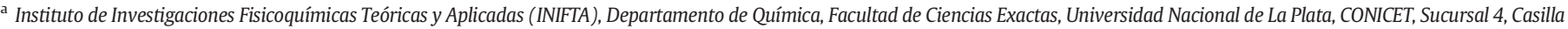 \\ de Correo 16, 1900 La Plata, Argentina \\ b Soft Matter Nanotechnology Group, CIC biomaGUNE, Paseo Miramón 182C, 20009 San Sebastián, Guipúzcoa, Spain
}

\section{A R T I C L E I N F O}

Article history:

Received 24 November 2016

Received in revised form 30 May 2017

Accepted 7 July 2017

Available online 13 July 2017

\section{Keywords:}

Polyelectrolyte multilayers

Thermal annealing

Cell adhesion

Bacteria adhesion

Topography

\begin{abstract}
A B S T R A C T
The development of antifouling coatings with restricted cell and bacteria adherence is fundamental for many biomedical applications. A strategy for the fabrication of antifouling coatings based on the layer-by-layer assembly and thermal annealing is presented. Polyelectrolyte multilayers (PEMs) assembled from chitosan and hyaluronic acid were thermally annealed in an oven at $37^{\circ} \mathrm{C}$ for $72 \mathrm{~h}$. The effect of annealing on the PEM properties and topography was studied by atomic force microscopy, $\zeta$-potential, circular dichroism and contact angle measurements. Cell adherence on PEMs before and after annealing was evaluated by measuring the cell spreading area and aspect ratio for the A549 epithelial, BHK kidney fibroblast, C2C12 myoblast and MC-3T3-E1 osteoblast cell lines. Chitosan/hyaluronic acid PEMs show a low cell adherence that decreases with the thermal annealing, as observed from the reduction in the average cell spreading area and more rounded cell morphology. The adhesion of S. aureus (Gram-positive) and E. coli (Gram-negative) bacteria strains was quantified by optical microscopy, counting the number of colony-forming units and measuring the light scattering of bacteria suspension after detachment from the PEM surface. A $20 \%$ decrease in bacteria adhesion was selectively observed in the S. aureus strain after annealing. The changes in mammalian cell and bacteria adhesion correlate with the changes in topography of the chitosan/hyaluronic PEMs from a rough fibrillar 3D structure to a smoother and planar surface after thermal annealing.
\end{abstract}

(c) 2017 Published by Elsevier B.V.

\section{Introduction}

Biological fouling, the deposition of proteins or other biomolecules and the formation of a biofilm are often a problem in the design of interfaces for biomedical devices in contact with biological fluids. The unspecific deposition of proteins and the formation of a biofilm can severely compromise the use of the coating or device for the intended biomedical applications as the presence of proteins or bacteria can lead to undesired biological responses or infections [1,2]. It is also often the case that the adherence of cells to medical device surfaces must be restricted, for example in surgery devices either during or post intervention [3,4]. Several approaches have been developed throughout the years for the functionalization of surfaces in order to make them antifouling, i.e.,

\footnotetext{
* Corresponding authors.

E-mail addresses: miguelp@inifta.unlp.edu.ar (M.A. Pasquale), azzaroni@inifta.unlp.edu.ar (O. Azzaroni), smoya@cicbiomagune.es (S.E. Moya).
}

pegylation, use of amphiphilic surfactants, biopolymer coatings, atomic layer deposition- modified polymeric coating, etc. [5-9]. The effectiveness of each approach usually depends on the degree of coverage of the surfaces and the stability of the coating with time. The reason why these antifouling coatings are effective is not always fully understood. The LbL technique is based on the alternating assembly of polyelectrolytes bearing opposite charges to form a thin film. The LbL technique is performed in aqueous media, it is simple and robust, and basically it only requires a charged surface for the assembly. The LbL technique has been used to produce coatings with antibacterial applications, with the capacity of releasing antibacterial agents, or capable of killing bacteria by contact, as well as surfaces combining the capacity of releasing of antibacterials with a low bacteria adhesion $[10,11]$. For biomedical applications, the control of mammalian and bacteria cells adhesion is a challenging task and of uppermost importance for the successful implementation of new material to be in contact with biological environments [12]. Multifunctional and intelligent interfaces, with good 
adhesion to certain type of cells and but limited adhesion to other cell lines, as well as with an effective response to specific cell functionalities find increasing applications in the biomedical field $[13,14]$. In the LbL deposition, besides polyelectrolytes other molecules [15,16], nanoparticles [17,18], lipid vesicles [19], and even cells $[20,21]$ can be assembled on top of multilayers or placed at selected positions in the PEMs, provided that they are charged or may exhibit other type of supramolecular interactions with adjacent layers. Thus, hybrid supramolecular biomaterials with potentially new properties can be developed. For instance, multilayered biomaterials, comprising high-molecular-weight biopolymers and oppositely charged low-molecular-weight peptide amphiphiles have been fabricated [22]. Furthermore, hybrid inorganic and organic materials that appear inspired by nature can be fabricated [23]. LbL based hybrid structures can include nanoparticles with multiple functions [24]. In particular hybrid organic / inorganic assembly can benefit from the multiple functionalities that can be carried by, inorganic nanoparticles with potential for gen delivery $[25,26]$ imaging, different type of disease treatment [27,28], and many other biomedical applications [29-31].

Among biopolymer coatings, chitosan-based ones are reported to have antifouling properties with limited protein adherence [32,33]. The layer-by-layer technique ( $\mathrm{LbL}$ ) offers a simple way to assembly chitosan as a dense coating [34,35]. Chitosan, as polycation, can be assembled with other biopolymers of biological origin bearing a negative charge, i.e., alginate or hyaluronate, resulting in a stable antifouling surface. It has been shown that chitosan/alginate coatings have good antifouling properties, with a restricted protein deposition when assembled on planar or colloidal surfaces. The authors coated poly(lactic-coglycolic) nanoparticles with chitosan/alginate with the objective of enhancing nanoparticle circulation for drug delivery applications [36].

Recently, Muzzio et al. have shown that by means of thermal annealing it is possible to increase cell adhesion to polyelectrolyte multilayers of poly-L-lysine (PLL) and alginate (Alg) [37]. Despite the fact that the annealing reduces the deposition of proteins on the multilayers, thus acquiring antifouling properties, cells adhere better to annealed PLL/Alg multilayers than to unannealed ones. Annealing increases contact angle notoriously for PLL/Alg multilayers, from approximately 30 to around $90^{\circ}$. This change in contact angle means that the multilayers become more hydrophobic, which can result in not only a decrease in the amount of deposited proteins but also in an interaction of the proteins with the surface that is more controlled by the hydrophobic regions of the proteins than by electrostatic interactions [38]. A different arrangement of proteins on the annealed PEMs could explain why with lower protein deposition cell adherence increases. This particular response to annealing is specific to PLL/Alg PEMs. Other PEMs based on biopolymers show different behavior in relation to protein and cell adherence when they are annealed, as we will show here.

In this work we place particular emphasis on the impact of thermal annealing on the antifouling properties of chitosan/hyaluronic acid (Chi/HA) multilayers for proteins, eukaryotic and bacteria cells. We show that Chi/HA multilayers behave as largely antifouling materials and thermal annealing enhances the antifouling characteristics of the PEMs. For these studies, four different eukaryotic cell lines and two bacteria strains were tested. Annealed Chi/HA PEMs were characterized by atomic force microscopy, contact angle, $\zeta$ - potential measurements, the quartz crystal microbalance technique and circular dichroism. Smoother, highly negative hydrophilic surfaces with very low protein deposition and enhanced resistance to both eukaryotic and bacteria cells were produced after annealing. Adhesion data from the tested eukaryotic cells show that the epithelial cell line studied exhibit nonadherent characteristics neither on the unannealed nor on the annealed PEM, while for the other cell lines there is a significant decrease in adhesion to the PEMs after annealing. In the case of bacteria, there is a specific decrease of adhesion for Gram-positive bacteria, which is not observed with Gram-negative ones. Thermal annealing modifies cell-film interactions to an extent that depends on the cell line and may be used as an alternative friendly method for modifying surface properties for biological applications.

\section{Materials and methods}

\subsection{Materials and reagents}

Chitosan (Chi, Mw 100-300 kDa, Cat. No. 349051000) and hyaluronic acid (HA, Mw 1500-2200 kDa, Cat. No. 251770010) were acquired from Acros Organics. HEPES sodium salt (H7006), phosphate buffered saline (PBS, D1408), sodium acetate trihydrate (AcNa, S8625), acetic acid ( $\mathrm{AcH}, 33,209)$, bovine serum albumin (BSA, A7906), fibronectin from human plasma (F1056), sodium dodecyl sulfate (SDS, L6026) and Minimum Essential Medium (MEM, M4526) were purchased from Sigma-Aldrich. Roswell Park Memorial Institute medium (RPMI, 12-702F) was acquired from Lonza.

\subsubsection{Multilayer film preparation via layer-by-layer ( $L b L)$ assembly}

PEMs were assembled on cover glasses entailing 15 layers of polyelectrolytes, the first and the last layer always being the polycation, $(\mathrm{Chi} / \mathrm{HA})_{7}$ Chi. Both polyelectrolytes were alternately assembled by manually dipping the cover glasses in the polyelectrolyte solutions for $15 \mathrm{~min}$ at $24{ }^{\circ} \mathrm{C}$. Cover glasses were cleaned by immersing them in $10 \mathrm{mM}$ SDS for $3 \mathrm{~h}$, rinsed in sterile water three times, treated with $0.1 \mathrm{M} \mathrm{HCl}$ overnight, and thoroughly rinsed in water.

Both polyelectrolyte solutions were prepared at a concentration of $1 \mathrm{mg} \mathrm{mL}^{-1}$ in a $150 \mathrm{mM} \mathrm{NaCl}, 10 \mathrm{mM}$ sodium acetate buffer ( $\mathrm{pH} 5$ ) (ACETATE Buffer) and filtered through a $0.45 \mu \mathrm{m}$ filter. After each layer deposition, films were rinsed 3 times with ACETATE Buffer.

\subsubsection{Multilayer film annealing}

PEMs prepared as described in previous section (unannealed PEM) were UV-sterilized for $1 \mathrm{~h}$ in the laminar flow hood and left in a Memmert UNE 200-300 oven at $37^{\circ} \mathrm{C}$ for $72 \mathrm{~h}$ for thermal annealing.

\subsection{Quartz crystal microbalance with dissipation (QCM-D)}

A QCM-D E4 device from Q-Sense was used to trace the assembly profile of the $\mathrm{Chi} / \mathrm{HA}$ film on top of a $\mathrm{SiO}_{2}(50 \mathrm{~nm})$ coated quartz crystal (5 MHz, Q-Sense). All experiments were performed at $24^{\circ} \mathrm{C}$. For each polyelectrolyte deposition, a $1 \mathrm{mg} \mathrm{mL}^{-1}$ polyelectrolyte solution in ACETATE buffer was flown through a 4-sensor chamber with the help of a peristaltic pump and left under incubation for $10 \mathrm{~min}$. Every deposition step was always followed by $10 \mathrm{~min}$ rinsing with the buffer solution. Experiments were also conducted to study the stability of the film in $10 \mathrm{mM}$ HEPES buffer containing $150 \mathrm{mM} \mathrm{NaCl}$ (HEPES buffer), and the adsorption of bovine serum albumin (BSA) and fibronectin (FN) proteins on the film before and after annealing on the quartz crystals. HEPES buffer was chosen for these experiments because it mimics cell growth conditions better.

\subsection{Protein adsorption}

BSA and FN were absorbed on PEMs at $24{ }^{\circ} \mathrm{C}$. Annealed and unannealed PEMs were immersed for $45 \mathrm{~min}$ in either $1 \mathrm{mg} \mathrm{mL}^{-1}$ BSA or $0.05 \mathrm{mg} \mathrm{mL}^{-1} \mathrm{FN}$ in HEPES buffer. The difference in concentration for the two proteins takes into account their relative abundance in cell media.

\subsection{Atomic force microscopy (AFM)}

The morphology of air-dried PEMs was studied with an AFM from Nanovizard II AFM (JPK, Berlin, Germany). Images were collected in tapping mode with TESP-V2 cantilever (Bruker, AFM Probes) with a nominal spring constant of $40 \mathrm{~N} \mathrm{~m}^{-1}$ oscillating near a resonant frequency in the range 280 to $320 \mathrm{kHz}$. 


\subsection{Contact angle measurements}

The wettability of PEMs was evaluated on air-dried samples in a DSA 100 contact angle measuring system (Kruss Company). The tangent angle of a three-phase contact point of a sessile drop profile of nanopure water on PEM surfaces was determined by optical imaging. The volume of the droplet was kept constant $(3 \mu \mathrm{L})$, while the velocity was set at $500 \mu \mathrm{L} \mathrm{min}^{-1}$. Four repetitions were conducted for each sample.

\section{6. $\zeta$ - potential measurements}

The surface charge of the PEM was assessed by measuring the $\zeta$ - potential on PEM coated colloidal $\mathrm{SiO}_{2}$ particles. For this purpose, $\mathrm{SiO}_{2}$ particles $5 \mu \mathrm{m}$ in diameter were first suspended in ACETATE buffer at $1 \mathrm{mg} \mathrm{mL}^{-1}$. Subsequently, the particles were incubated with the polyelectrolyte solution $\left(1 \mathrm{mg} \mathrm{mL}^{-1}\right)$ for $15 \mathrm{~min}$. The procedure was repeated for every deposited layer up to 15 layers. In between polyelectrolyte depositions, three washing steps were performed via centrifugation. $\zeta$ potential measurements were carried out employing a Malvern Zetasizer with a disposable folded capillary cell at $25{ }^{\circ} \mathrm{C}$, applying a cell drive voltage of $40 \mathrm{~V}$ and using a monomodal analysis model. Three repetitions were conducted for each sample. Samples were diluted in either HEPES or ACETATE buffers at a final concentration of $0.2 \mathrm{mg} \mathrm{mL}^{-1}$.

\subsection{Circular dichroism}

Circular dichroism (CD) spectra of air dried films were measured with a Jasco J810 instrument. Measurements were run on samples before and after different annealing times. For this purpose, PEMs were assembled on high-quality quartz cover glasses (Electron Microscopy Science). CD measurements were also performed to trace structural changes of proteins adsorbed on the samples. After adsorption of BSA and FN from HEPES buffer, samples were rinsed gently with water and dried under nitrogen. Measurements were performed in a spectral range from 300 to $190 \mathrm{~nm}$, and each spectrum was obtained by averaging 4-16 scans. The instrument was calibrated with (1R) (-)10camphorsulfonic acid ammonium salt. All measurements were carried out at $24^{\circ} \mathrm{C}$.

\subsection{Eukaryotic (mammalian) cell culture}

A549 epithelial cells, a human lung carcinoma cell line; BHK, a fibroblast cell line from baby hamster kidney; $\mathrm{C} 2 \mathrm{C} 12$, a mouse myoblast cell line; and MC-3T3-E1 murine osteoblast cells were employed as eukaryotic cell lines model for adherence studies. The first three cell line were grown in RPMI medium and the latter in MEM, supplemented with $10 \%$ FBS and antibiotics, and incubated at $37{ }^{\circ} \mathrm{C}$ in a $5 \% \mathrm{CO}_{2}$ humidified atmosphere.

For adhesion assays, glass and films were placed in Petri dishes $35 \mathrm{~mm}$ in diameter (Falcon) and UV-sterilized for $1 \mathrm{~h}$. Then, $5 \times 10^{4}$ cells in $3 \mathrm{~mL}$ culture medium were seeded on top. Phase-contrast images were taken at 24 and $48 \mathrm{~h}$ employing a Nikon T100 inverted microscope with a CFI flat field ADL $10 \times$ objective.

\subsubsection{Quantification of mammalian cell adhesion}

Cell adhesion and cell spreading characteristics were quantified 24$48 \mathrm{~h}$ after seeding. For this purpose, cell contours were manually traced using a Wacom graphic tablet and analyzed using Image-Pro Plus 6.0 software, Media Cybernetics Inc. The cell area in $\mu^{2}$, the aspect ratio measured as the ratio between the major axis and minor axis of an ellipse with an area equivalent to that of the cell, and roundness measured as perimeter ${ }^{2} 4^{-1} \pi^{-1}$ area $^{-1}$, were determined. A roundness of 1 corresponds to a rounded cell whereas higher values are associated with cells having longer perimeter and limited area, as in the case of cells with a tapered morphology, high roughness or both.
Differences in the average cell adhesion area and morphological parameters for each tested substrate were evaluated utilizing one-way analysis of variance (ANOVA) and Fisher test with a significance level $p=0.05$.

\subsection{Bacteria cell culture}

Gram-negative enterobacteria E. coli and Gram-positive S. aureus strains were cultured in Luria Broth (LB) medium in an incubator at $37{ }^{\circ} \mathrm{C}$ with constant shaking at $200 \mathrm{rpm}$. Adhesion assays on unannealed and annealed PEMs were performed by immersing the films in a $35 \mathrm{~mm}$ diameter Petri dish containing $2 \mathrm{~mL}$ of a bacteria suspension of $4 \times 10^{7} \mathrm{CFU} \mathrm{mL} \mathrm{m}^{-1}$ and incubating for $2 \mathrm{~h}$ at $37^{\circ} \mathrm{C}$ without shaking. Subsequently, the films were gently rinsed in PBS to remove non adhered bacteria and the number of adhered cells was evaluated by two different procedures. (I) Direct observation of films under a microscope at $20 \times$ magnification. (II) Removing the adhered bacteria by immersion of the films in a tube containing $3 \mathrm{~mL}$ of fresh PBS and sonication for $10 \mathrm{~min}$ in a sonicator bath, and counting the number of colony forming units (CFU) present in the suspension. Then $100 \mu \mathrm{L}$ of different dilutions of the obtained suspension was plated in LB agar plates and after $24 \mathrm{~h}$, the number of CFU in the appropriate concentration was measured. In another set of experiments, the concentration of bacteria was assessed by measuring light scattering from a $600 \mathrm{~nm}$ UV source with a Jasco Spectrometer UV-visible. Three independent experiments were performed for each condition, and the standard error was determined.

\section{Results and discussion}

\subsection{QCM-D data}

The assembly of Chi/HA PEMs from ACETATE buffer was followed by QCMD. The frequency $(\triangle \mathrm{F})$ decreased after each polyelectrolyte assembly following a quasi- exponential law with the number of layers (Fig. 1a and b). In Fig. 1a, the odd and even numbers correspond to the deposition of the polycation and the polyanion, respectively. After the PEM assembly, HEPES buffer ( $\mathrm{pH} 7.4$ ) was flown into the QCMD chamber. Then, the frequency increased by about $70 \mathrm{~Hz}$, i.e., a $20 \%$ of the total frequency after film assembly, but remained stable afterwards. This means that in cell media part of the film is removed but the multilayer remains assembled. It is worth noting that for HEPES and ACETATE buffers, most of the ionic species correspond to $\mathrm{NaCl}$, and the change in $\mathrm{pH}$ from one buffer to the other should be the most relevant factor leading to a partial disassembling of the film.

\subsection{Circular dichroism}

CD measurements were performed on unannealed samples and after annealing for 1 and 2 days (Fig. 1c). At low wavelengths, the CD angles become more negative with the time of annealing. The $\mathrm{CD}$ technique is extremely useful for peptide characterization [39] and has been previously applied to trace PEM assembly [40,41], and it has been shown that the $\mathrm{CD}$ signal increases with the number of deposited layers. Our data exhibit an increase in the $\mathrm{CD}$ signal with the time of annealing. Such an increase without additional deposition of polyelectrolyte layers can be interpreted as a densification of the PEMs, i.e., the compactness of the film increases after the annealing process.

\subsection{Contact angle and $\zeta$ - potential measurements}

Contact angle values were determined on unannealed and annealed Chi/HA PEMs. The former exhibited a contact angle of $30.2^{\circ} \pm 0.3^{\circ}$, and after annealing the contact angle decreased to values of $20.6^{\circ} \pm 1.8^{\circ}$. From these data we can conclude that although the unannealed PEMs are hydrophilic, the thermal annealing increases the hydrophilic character of the PEMs (Table 1). 


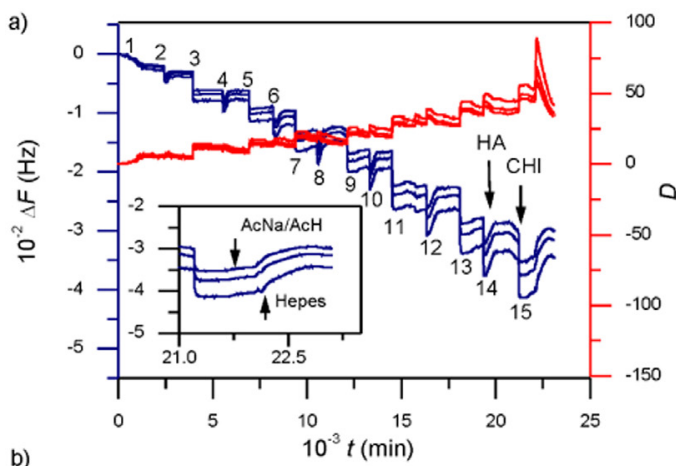

b)

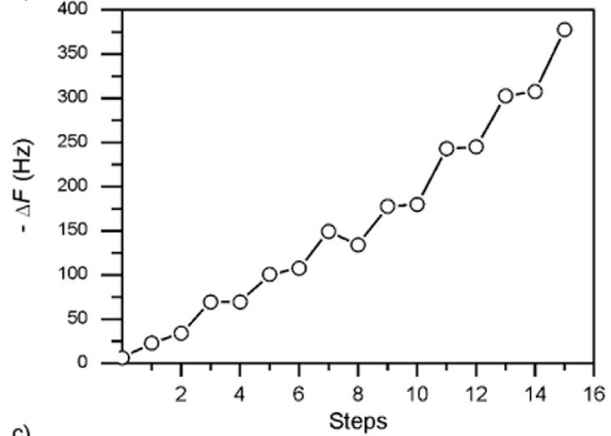

c)

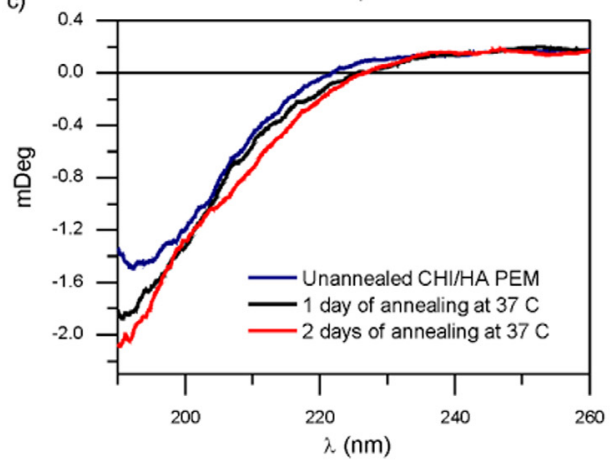

Fig. 1. (a) QCM-D data from (Chi/HA) ${ }_{7}$ Chi polyelectrolyte multilayer assembly. Frequency variations are shown in blue and dissipation in red. The inset shows the change in frequency due to the flow of HEPES buffer without polyelectrolytes. (b) $-\Delta \mathrm{F}$ versus number of layer plot from data shown in (a). (c) CD spectra from (Chi/HA) ${ }_{7} \mathrm{Chi}$ polyelectrolyte multilayer, unannealed and annealed for 1 and 2 days, as indicated in the plot. (For interpretation of the references to colour in this figure legend, the reader is referred to the web version of this article.)

The $\zeta$ - potential measurements (Table 1 ) show that the sign and value of the charge of the multilayers depends on the medium in which the potential was determined as a result of the specific adsorption of ions from the buffer and the changes in the film due to the $\mathrm{pH}$ of the HEPES buffer. While in ACETATE buffer the potential is positive, in HEPES buffer it becomes negative. The annealing does not alter the sign of the charge but affects the absolute value of the potential. In the HEPES buffer, the $\zeta$ - potential changes from $-24 \mathrm{mV}$ for the unannealed PEM, to $-31 \mathrm{mV}$ in the annealed one. The partial disassembly of polyelectrolyte from the film, mainly due to the variation in $\mathrm{pH}$, and the interchange between the species present in each buffer would contribute to the change in $\zeta$ - potential. In any case the film, after the washing step, remains stable.

\subsection{Atomic force microscopy}

AFM images of Chi/HA PEMs were taken from unannealed and annealed samples previously immersed in HEPES for $40 \mathrm{~min}$. In Fig. 2a-f both surfaces are shown at three different scales. The comparison of the topography between annealed and unannealed PEMs indicates that the annealed ones become smoother from the microscale downwards. At the highest scale, i.e., $50 \mu \mathrm{m}$, the annealed PEM exhibits fewer but larger protrusions. These protrusions exhibit an asymmetric form with increased height, reaching $30 \mathrm{~nm}$ on average. When we reduce the scale to 5 and $1 \mu \mathrm{m}$ the annealed surface forms a mesh with a structure of clusters with a strong fractal resemblance that reaches an average height of $6.2 \mathrm{~nm}$, being more planar than the unannealed surface, which at the same scale displays an average height of about $14.9 \mathrm{~nm}$ (Fig. 2g). For the annealed surface, the fiber-like structure appears to be percolated, and the fractal dimension of the projected structure calculated by the box counting method results in 1.42. As a consequence of the annealing, the fiber-like structure turns more bidimensional and it is possible to appreciate that the surface is more homogenously covered by the polymer network. The roughness ( $R q$ ) calculated from the $5 \times 5 \mu^{2}$ images is $9.4 \pm 0.6$ for the unannealed PEM and $3.3 \pm 0.1 \mathrm{~nm}$ for the annealed one (Fig. $2 \mathrm{~g}$ ). These figures lie in the range of the focal contact dimensions of most cells [42,43].

The profiles of the $5 \times 5 \mu \mathrm{m}^{2}$ images from the annealed and unannealed PEM surfaces are shown in Fig. 2h. For the unannealed PEM, the presence of valleys between peaks higher than about 20$30 \mathrm{~nm}$ with $1 \mu \mathrm{m}$ separation can be distinguished. On the other hand, peaks of 5-10 nm in height are randomly distributed on the annealed surface; with an average separation of the order of $0.1 \mu \mathrm{m}$. Height distributions (Fig. 2i) from the unannealed and annealed PEMs are consistent with these observations. Thus, for the annealed PEM the height distribution exhibits a single maximum close to $5 \mathrm{~nm}$, but for the unannealed one a sharp peak appears at 5-6 nm and a plateau, from 8 to $20 \mathrm{~nm}$.

In previous work we have showed that thermal annealing on PLL/Alg multilayers causes the multilayers to reorganize, resulting in a smoother film with a higher contact angle, meaning that the surface becomes more hydrophobic [38]. The film becomes thinner after annealing and there is an apparent increase in the elasticity modulus. Concomitant with these changes, the deposition of proteins from media on the surface decreases but in parallel, cell adherence increases. In this case, the increase in cell adherence could be explained by the increase in the mechanical properties of the film or by a more favorable conformational arrangement of the depositing proteins for the cells to adhere.

AFM measurements of Chi/HA PEMs after immersion in HEPES buffer and dried in air, revealed that the surface becomes smother at the sub-micrometer scale with the annealing (Fig. 2), as in the case of PLL/ Alg PEMs, but while for the latter, a granular homogeneous structure is formed, for Chi/HA PEMs a fibrillar network can be distinguished. The thermal annealing causes the fibers to become thinner and more bidimensional, i.e., the surface is covered with structures having an average height close to $5 \mathrm{~nm}$, a value significantly smaller than those measured for the unannealed PEM. The elasticity of Chi/HA PEMs was determined from nanoindentation experiments (Supplementary material, Fig. S1). In contrast to the changes in the Young modulus observed for PLL/Alg multilayers, no conclusive Young modulus differences between unannealed and annealed Chi/HA PEMs could be determined.

Furthermore, the rearrangement of the Chi/HA polyelectrolyte pairs, induced by the thermal annealing, makes the surface remain

Table 1

Contact angle measurements on Chi/HA PEMs and $\zeta$ - potential measured on Chi/HA coated nanoparticles in both HEPES and ACETATE buffers.

\begin{tabular}{|c|c|c|c|}
\hline & $\zeta$ - potential HEPES Buffer $(\mathrm{pH}=7.4) / \mathrm{mV}$ & $\zeta$ - potential ACETATE Buffer $(\mathrm{pH}=5.1) / \mathrm{mV}$ & Contact angle \\
\hline Unannealed PEM & -24 & 25 & $30.2 \pm 0.3$ \\
\hline Annealed PEM & -31 & 18 & $20.6 \pm 1.8$ \\
\hline
\end{tabular}




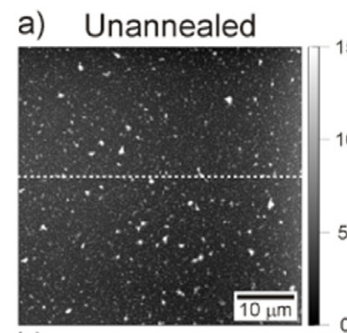

b)

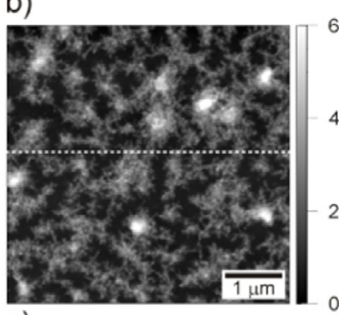

c)

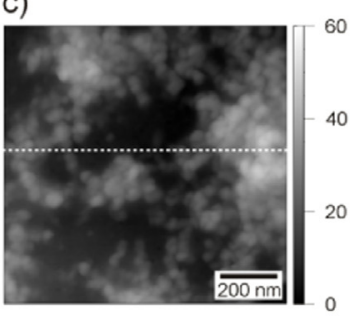

g)

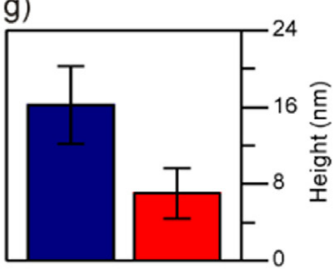

Unannealed$$
\text { (1) }
$$

d) Annealed

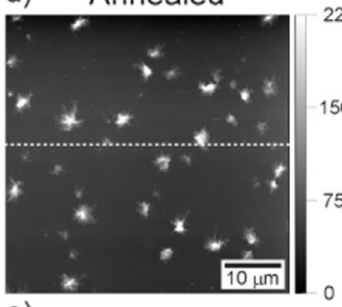

e)

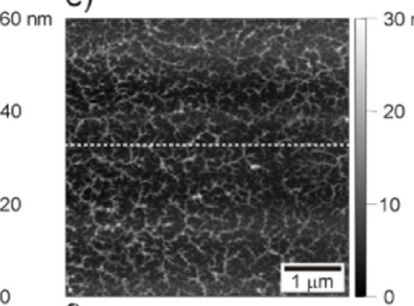

f)

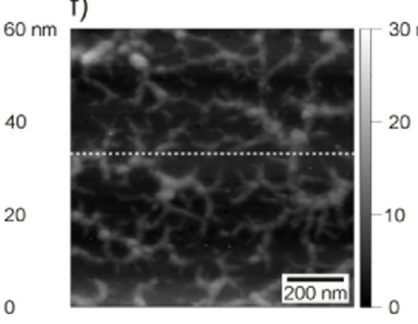

\section{.}

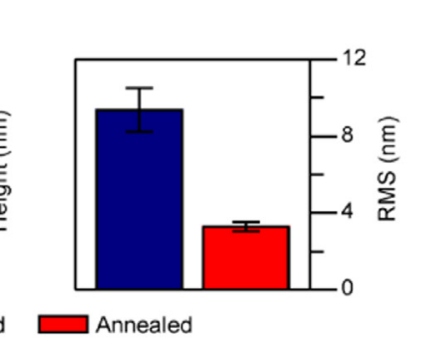

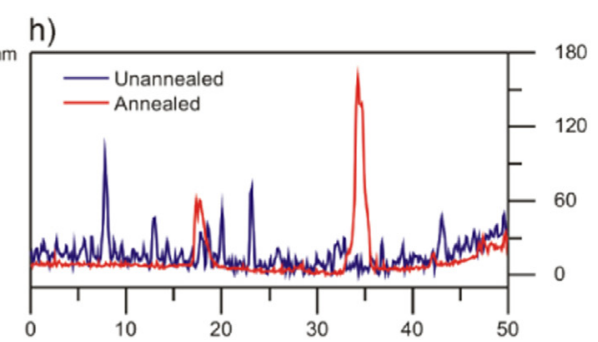
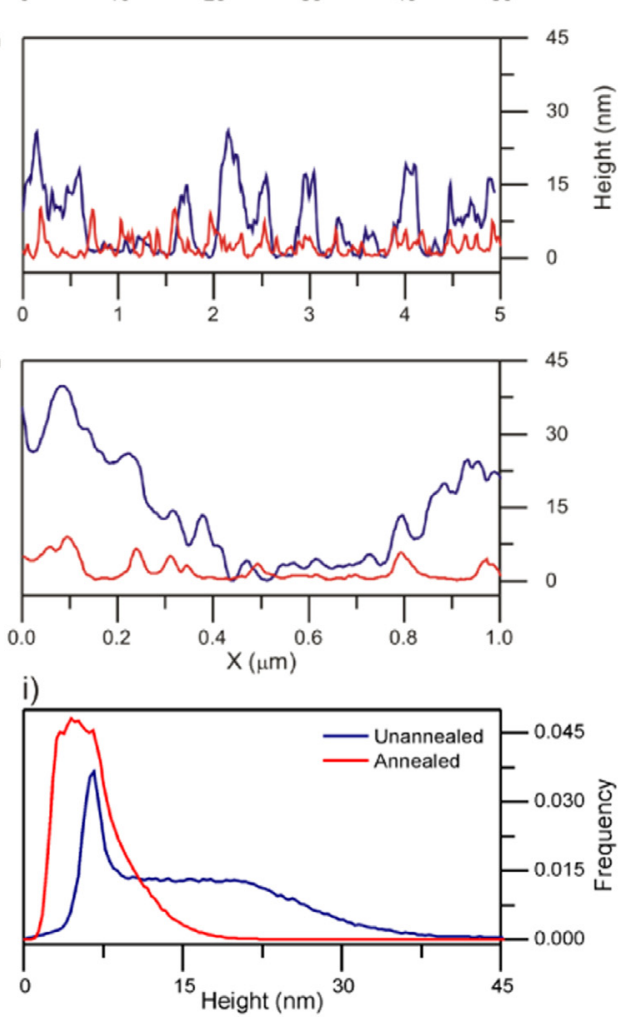

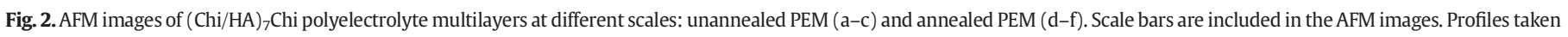

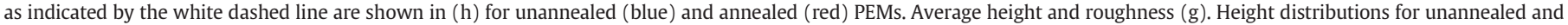
annealed PEMs (i). (For interpretation of the references to colour in this figure legend, the reader is referred to the web version of this article.)

hydrophilic; although we can hypothesize that similarly as in PLL/Alg, the chains rearrange to form complexes where there is a closer interaction between the oppositely charged polyelectrolytes. The complexes remain, however, in the form of fibers and retain a negative charge after the washing step. Even though the polymer coating seems to be more homogeneously distributed on the surfaces with less free space between fibers, the coating is far from reaching the density of more globular polymers as in the case of PLL/Alg PEMs after annealing. Both $\zeta$ - potential and contact angle measurements (Table 1 ) point out that the hydrophilicity of the film is not significantly altered by the annealing, probably because the fibrillar arrangement is maintained and the charges cannot be further neutralized in these conditions.

\subsection{Antiadhesive properties}

Bovine serum albumin and fibronectin proteins in HEPES buffer at a concentration of $1 \mathrm{mg} \mathrm{mL}^{-1}$ and $50 \mu \mathrm{g} \mathrm{mL}^{-1}$ respectively, were used as model proteins. These proteins were chosen because the first is the most abundant protein in cell media and the second mediates on cell adherence processes.

A limited protein adhesion to unannealed and annealed PEMs was observed by means of the QCM-D technique (data not shown). The change in frequency results in a few Hertz as BSA solution in HEPES buffer is passed through the chamber, with crystals previously coated with the PEMs and stabilization post-washing, irrespective of the annealing process.

For FN, the same trend is observed. Thus, these experiments do not provide conclusive results about the differences between unannealed and annealed PEMs. It is worth noting that FN in an amount as low as $20 \mathrm{ng} \mathrm{cm}^{-2}$ is expected to enhance cell adhesion to self-assembled monolayers of alkanethiols on gold [44], an amount close to the error of the QCM-D measurements.

On other hand, CD data (see Supplementary material Fig. S2) show a small adhesion of FN to both annealed and unannealed PEMs. The presence of FN on PEMs is evidenced by the appearance of small peaks in the spectra in the $230-210 \mathrm{~nm}$ and $190-180 \mathrm{~nm}$ wavelength ranges, which are more clearly distinguished for the unannealed PEM. The two mounds that appear in the $210-230 \mathrm{~nm}$ range are characteristic of the $\alpha$-helix conformation. This fact may indicate a different structure of the adsorbed FN on each PEM.

In comparison with the PLL/Alg films [37], Chi/HA films show a more antifouling character, there is a limited protein deposition on the film, barely detected by QCM-D, at least under our experimental conditions.

\subsubsection{Mammalian cell adhesion}

The cells utilized in these experiments are very different in nature: tumor epithelial cells from human lung, fibroblasts from the kidney of a hamster, mice osteoblasts and myoblasts. The latter three cell lines 
a)
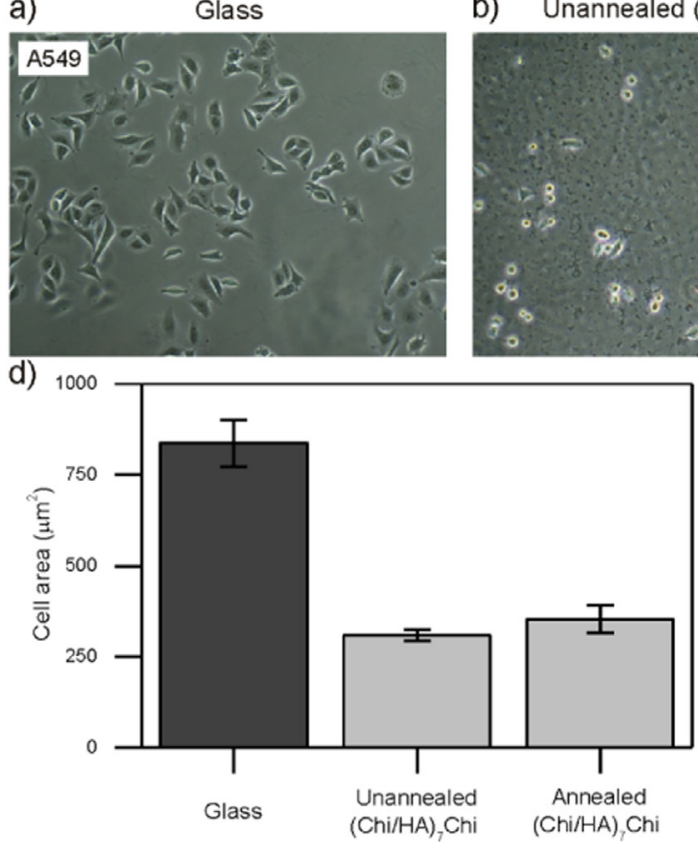

b) Unannealed (Chi/HA) $\mathrm{Chi}$
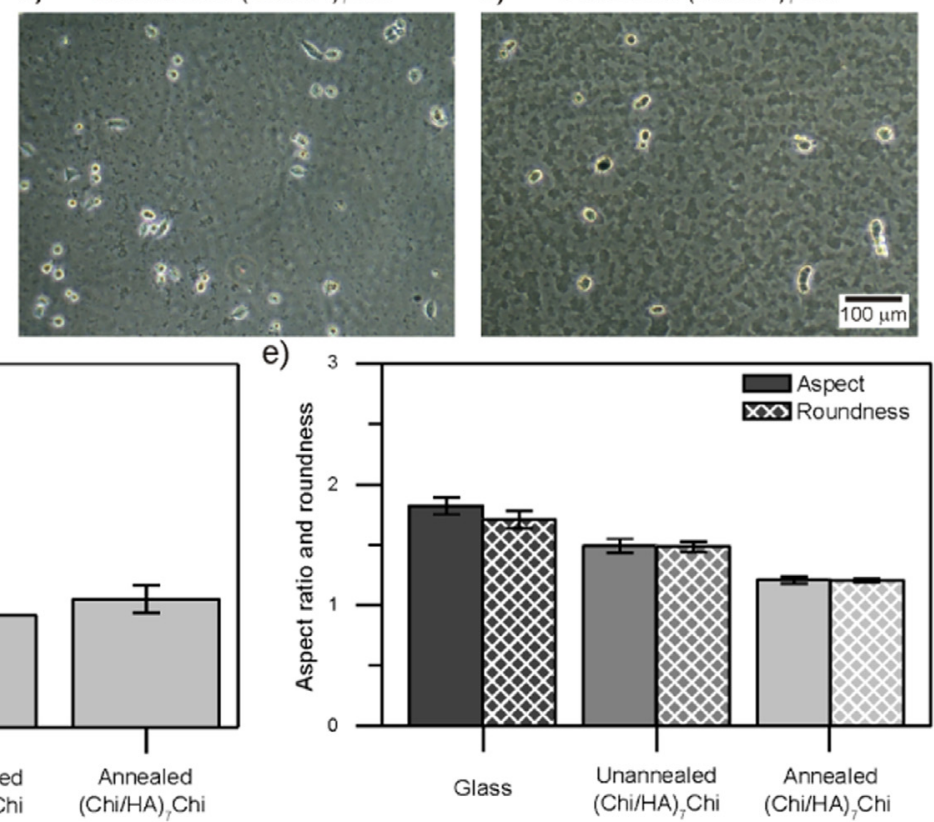

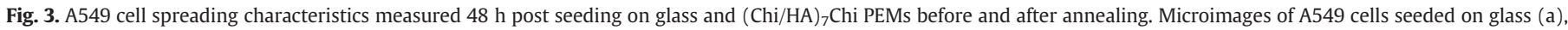

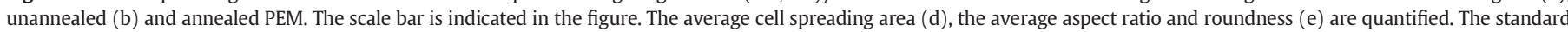
error is included in the histograms. Significant differences $(p=0.05)$ in data are indicated in gray scale.

are fibroblastic in shape, with a high polarization, whereas the former tend to be more rounded. Morphological parameters measured in this work were in agreement with these characteristics.

Chi/HA PEMs (Figs. 3-6) exhibited a significant effect on cell adhesion. A549 cells poorly adhere to these films, either to the unannealed or to the annealed PEMs (Fig. 3b,c), with an average spreading area close to $310 \mu \mathrm{m}^{2}$, and average aspect ratio and roundness significantly smaller than those obtained from cells seeded on glass (Fig. 3d,e). Thus, most cells were rounded in shape, in agreement with their low adhesion; their average aspect ratio and roundness tended to 1 in going from unannealed PEMs to annealed ones (Fig. 3e).

In the case of the $\mathrm{C} 2 \mathrm{C} 12$ cell line, the adhesion properties significantly decreased from the unannealed Chi/HA PEMs to the annealed PEMs (Fig. 4). As the duplication rate of these cells is larger than that of the other cell lines employed, adhesion characteristics were analyzed mainly at $24 \mathrm{~h}$ post-seeding. At this time, C2C12 cells adhere to unannealed PEMs, although exhibiting a different aggregation pattern in comparison with cells on glass (Fig. $4 \mathrm{a}$ and b). After $48 \mathrm{~h}$ post- seeding, cells a)
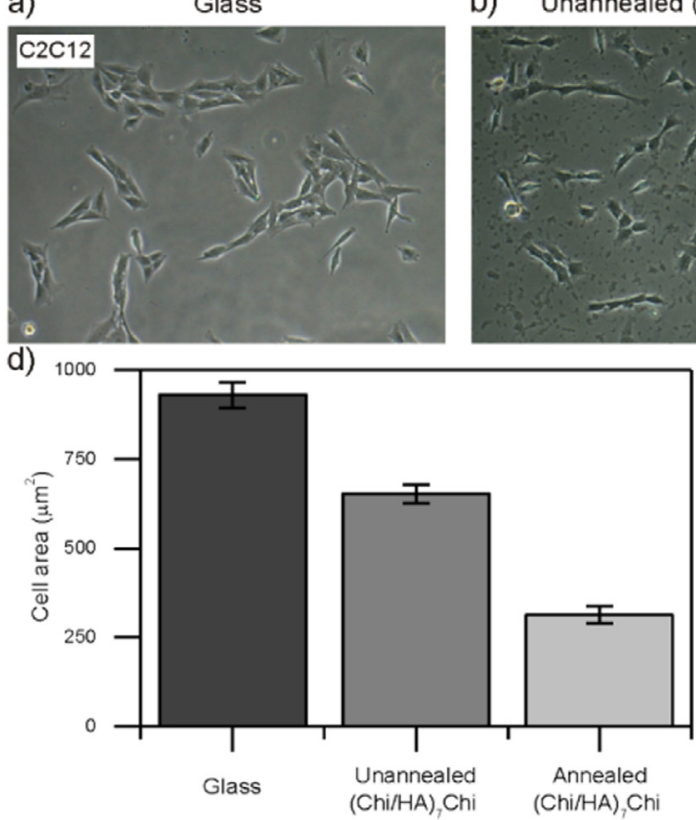

b) Unannealed (Chi/HA) $\mathrm{Chi}$

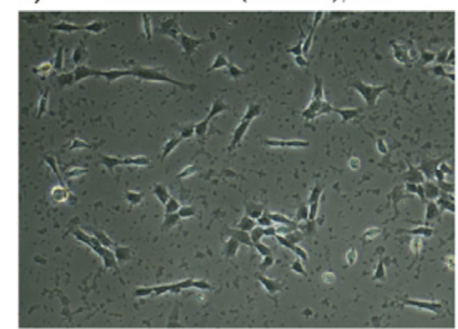

e) c) Annealed (Chi/HA),Chi
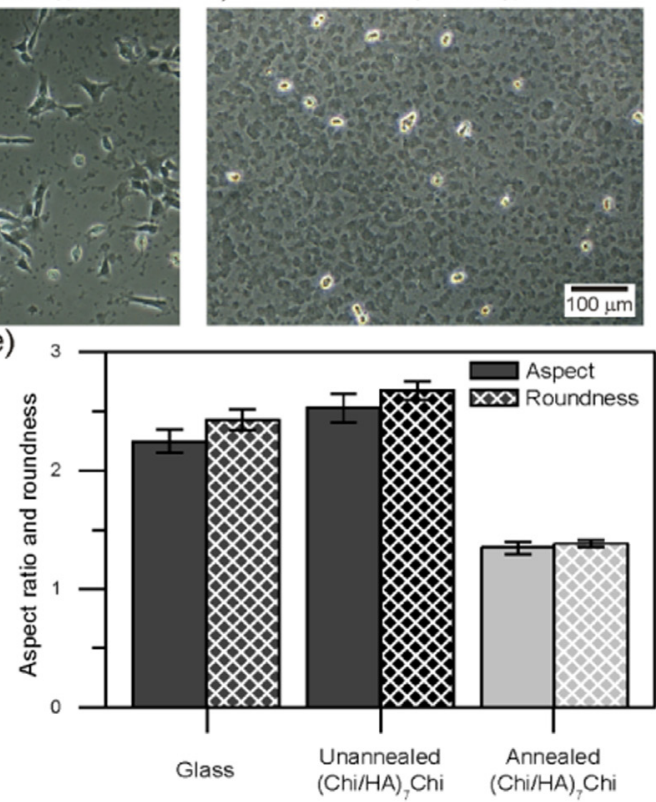

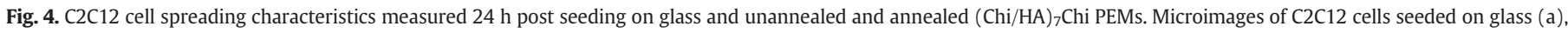

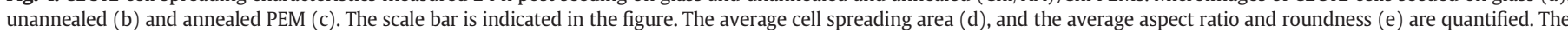
standard error is included in the histograms. Significant differences $(p=0.05)$ in data are indicated in gray scale. 
a)
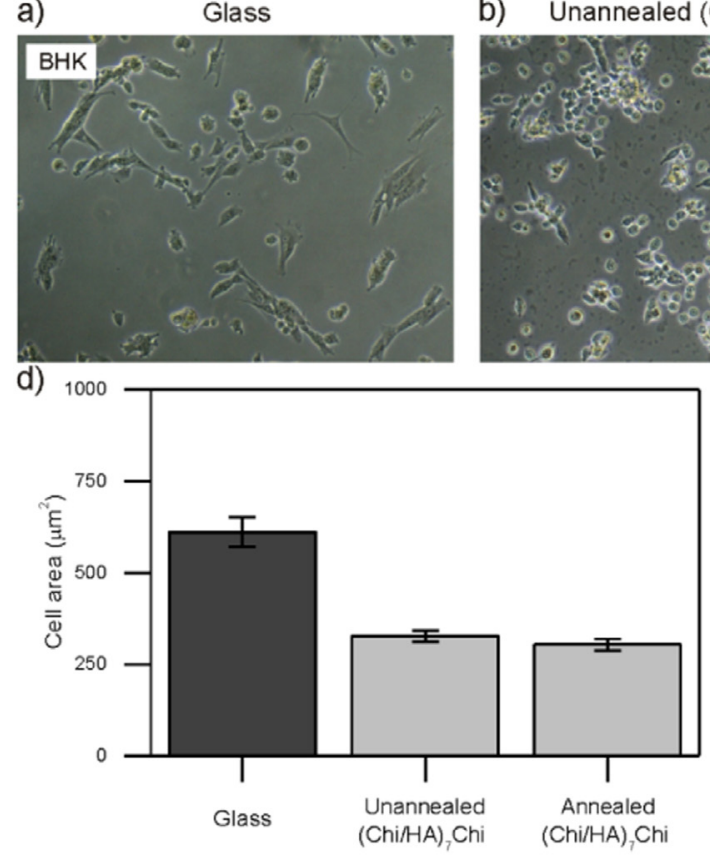

b) Unannealed $(\mathrm{Chi} / \mathrm{HA})_{2} \mathrm{Chi}$

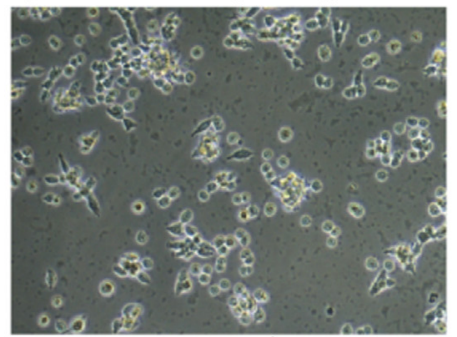

c) Annealed (Chi/HA) ${ }_{7} \mathrm{Chi}$

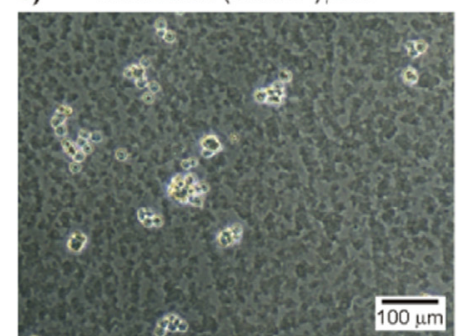

e)

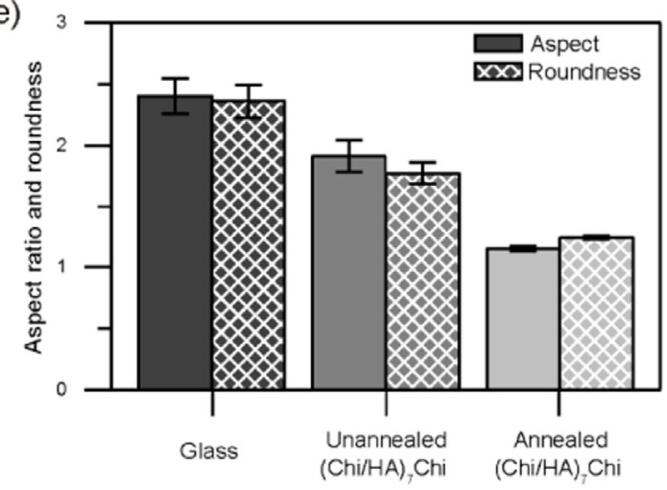

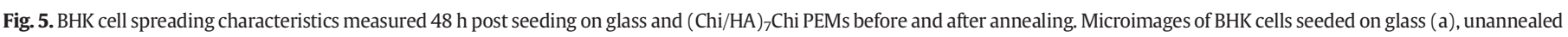

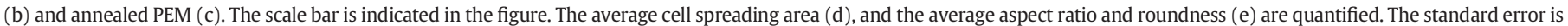
included in the histograms. Significant differences $(p=0.05)$ in data are indicated in gray scale.

tend to form small colonies with an outermost layer of highly ordered and polarized cells in the radial direction. On annealed PEMs cell adhesion was scarce (Fig. 4c).

The average spreading area of cells seeded on glass, the unannealed PEM and the annealed PEMs resulted in 930, 650 and $310 \mu \mathrm{m}^{2}$, respectively (Fig. 4d). Furthermore, the average aspect ratio and roundness of cells on the annealed PEMs were in the 1.3-1.5 range, figures which are smaller than those of cell on glass (2.2-2.5). Cells on the unannealed film exhibited roundness values a bit larger than on glass, i.e., a figure close to 2.7 was measured on the control PEM (Fig. 4e).

For BHK cells, a similar trend to that described for C2C12 cells was observed, although a larger decrease in cell adhesion to the unannealed PEM can be appreciated (Fig. 5); this fact can be inferred not only by the average spreading cell area, but also by the number of attached cells. A relatively small value in the average cell spreading area, and both their average aspect ratio and roundness close to 1 were observed for a)
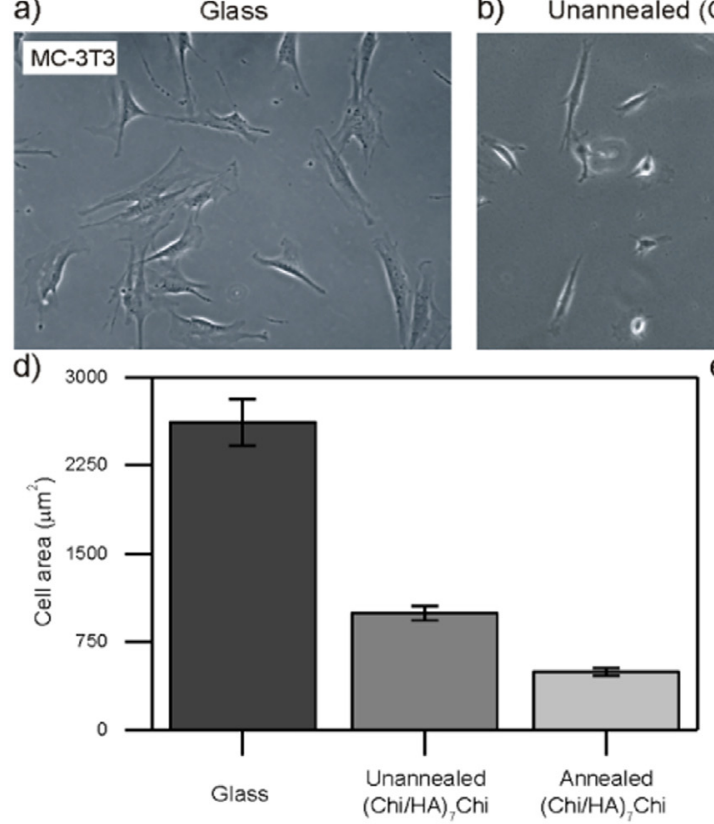

b) Unannealed (Chi/HA) Chi

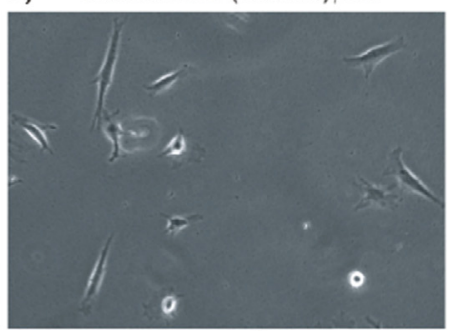

c) Annealed (Chi/HA) $)_{7}$ hi
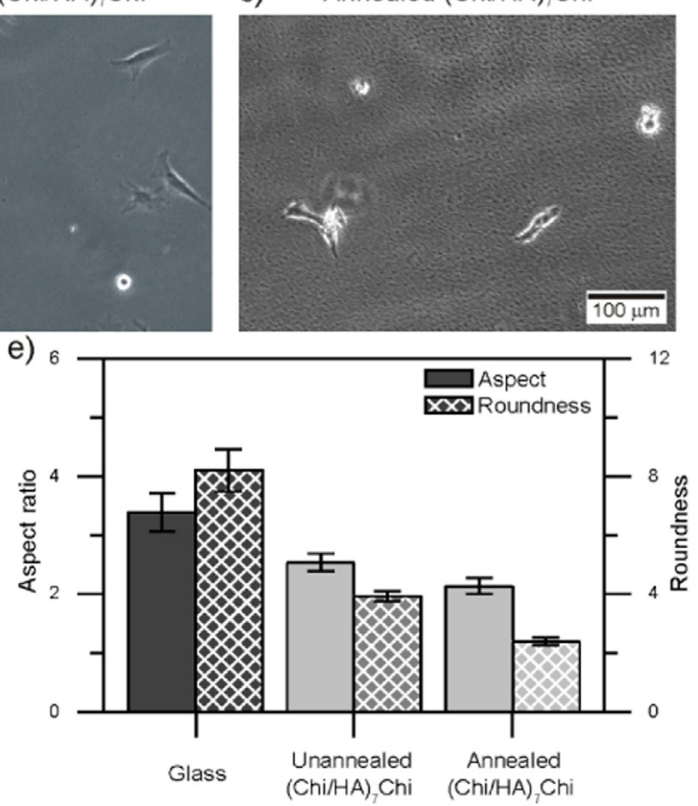

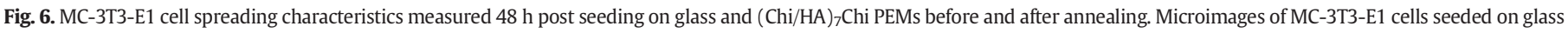

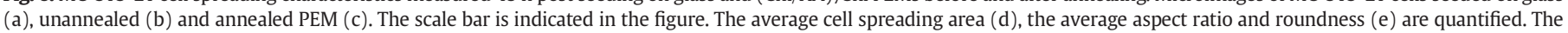
standard error is included in the histograms. Significant differences $(p=0.05)$ in data are indicated in gray scale. 
cells seeded on annealed PEMs. The average spreading areas on PEMs changed from $330 \pm 15 \mu \mathrm{m}^{2}$ on the unannealed PEM to $300 \pm 15 \mu \mathrm{m}^{2}$ on the annealed one; the aspect ratio followed the same trend.

However, MC-3T3-E1 cells adhered to unannealed films with a spreading area significantly smaller than that obtained on glass. The adhesion became poorer on annealed PEMs, and cells appeared rounded in shape (Fig. 6). The average cell spreading area changed from $1000 \pm 60$ $\mu \mathrm{m}^{2}$ before annealing to $500 \pm 30 \mu \mathrm{m}^{2}$, after annealing. Both the roundness and aspect ratio tended to diminish in going from the unannealed to the annealed PEM.

To sum up, cell adherence was low on the films before annealing and is cell type dependent. Some cell lines such as A549 practically did not adhere to the nonannealed films, and the adherence was not much altered by the annealing. In general, $\mathrm{C} 2 \mathrm{C} 12$ myoblast, BHK fibroblast and MG-3T3-E1 osteoblast showed less adhesion on the PEMs than in glass, but when the film was annealed they showed a further significant decrease in adherence.

A plausible explanation of the above results on eukaryote cell adherence can be found in the morphological changes that are produced by the annealing process, at least at the micrometer scale. From the comparison of the physic-chemical properties of unannealed and annealed Chi/HA PEMs, we can conclude that in both cases the PEMs are negatively charged, hydrophilic, exhibit a limited protein adsorption, and present similar mechanical properties. Thus, topographic changes produced during the annealing process are likely to be responsible for the variations in cell adhesion. It has been extensively reported that the topographic characteristics of the substrate at different size scales have a large influence on cell functionality $[45,46]$. In general, cells tend to adhere to rougher surfaces displaying features at the micro and nanoscale. Annealed Chi/HA PEMs show less roughness and are more planar, and cover the substrate more homogenously. These facts are coherent with a lower cell adhesion.

Protein adsorption plays a fundamental role in cell adhesion. Besides the amount of deposited proteins, their conformational state can influence the cell adhesion process. Proteins adsorbed on a surface require conformational changes to promote cell adhesion; specific protein arrangements are fundamental for the formation of focal contacts by mammalian cells [47-49]. Changes in FN conformation on surfaces with different roughness, have been suggested in the literature [5052]. The conformation of the FN protein on PEMs may be affected by the annealing, as can be appreciated from CD measurements for FN adsorbed on PEMs (Fig. S2 Supplementary material). CD data show the adsorption of FN on both unannealed and annealed PEMs, but suggest that the conformation of FN is different when deposited on one or another. This could also impact on the observed cell adherence behavior. Further experiments are planned to study protein conformation on the annealed PEMs.

\subsubsection{Bacteria cell adhesion on PEMs}

E. coli and S. aureus were cultured on PEMs in LB media for $2 \mathrm{~h}$ and subsequently gently rinsed in PBS, fixed with $4 \%$ formaldehyde and stained with DAPI at a concentration 1:1000 in PBS (Fig. 7). Microimages obtained from bacteria on glass exhibit a large coverage, i.e., $2.3 \times 10^{4}$ $\mu \mathrm{m}^{2}$ for S. aureus and $6.9 \times 10^{4} \mu \mathrm{m}^{2}$ for E. coli (Fig. 7b), as it can be inferred from the fluorescent spots. The bacteria surface coverage of the unannealed and annealed PEMs decreases rather abruptly for both bacteria strains. The annealing process significantly enhances the antifouling characteristics only for S. aureus, as it can be seen in the microimages and the corresponding histograms, with a decrease close to $18 \%$ for the annealed PEM in comparison with the unannealed one.

From the microimages the difference in the morphology of both bacteria can be appreciated; while $S$. aureus is rounded in shape, E. coli is tapered. It is worth noting that the determination of the covered area may be affected considerably by the image treatment. Therefore, to make the comparison among images feasible, in all the cases the same filter and threshold levels were employed.
To confirm the above results, the adsorption of E. coli and S. aureus bacteria was evaluated by counting the number of CFU that appear after platting $100 \mu \mathrm{L}$ of different dilutions of the suspension of bacteria obtained by sonicating the unannealed and annealed PEMs with adhered bacteria in fresh PBS as indicated in the experimental section. The results are summarized in Fig. 8a. For both bacteria strains on glass, similar values of CFUs were counted, i.e., $(5.6 \pm 0.3) \times 10^{6} \mathrm{CFU}$ for $S$. aureus and $(6.0 \pm 0.5) \times 10^{6} \mathrm{CFU}$ for $E$. coli. For both bacteria strains, adhesion to PEM was about fivefold smaller than on glass. For S. aureus a further $20 \%$ decrease in adhesion was measured for annealed PEMs in comparison with unannealed ones (Fig. 8a); the CFU value decreased from 13.4 to $11.4 \times 10^{5}$.

In another set of experiments, bacteria adhesion to the unannealed and annealed PEMs was quantified from the measurement of the absorbance of the bacteria detached by sonicating the samples in fresh BD medium (Fig. 8b). Measurements were performed every hour for $5 \mathrm{~h}$. The increase in the absorbance, which is produced by the increase in the cell number due to their duplication in BD medium, increased almost exponentially with time. Data from S. aureus showed a lower absorbance for annealed PEMs, which was more clearly observed at longer times. This is consistent with results obtained from fluorescence images as shown above (Fig. 7). For E coli the difference in adhesion was much smaller than for $S$. aureus, although a decreasing trend in adhesion for the annealed PEMs can be roughly distinguished.

To analyze the different adhesion characteristics of bacteria on unannealed and annealed PEM surfaces (Figs. 7 and 8), it is useful to briefly consider some general characteristics of the cellular wall of both bacteria employed in this work [53]. S. aureus gives a Gram-positive staining and E. coli is a Gram-negative bacteria. The cellular wall of the former bacteria that surround the internal cellular membrane is composed of a 20-80 nm thick peptidoglycan layer that also contains a certain amount of teichoic acid, a polymer of glycerol and ribitol groups bound to each other by phosphate groups and decorated with amino acid and monosaccharides [54]. Furthermore, lipoteichoic acids are present and bind the cellular wall with the plasmatic membrane of the cell [55]. Due to its negative charge, teichoic acids are in part responsible for the negative charge of Gram-positive bacteria surfaces. For $S$. aureus strains an $\zeta$ - potential between $-5 \mathrm{mV}$ and $-50 \mathrm{mV}$ has been reported, depending on the conditions and techniques employed for the measurements [56-58]. On the other hand, the Gram-negative bacteria cellular wall is much more complex than Gram-positive ones. In this case, the layer of peptidoglycan constitutes $5 \%-10 \%$ of the wall, which is about $2 \mathrm{~nm}$ in thickness and is located between the plasmatic membrane and the external membrane. The latter is composed of lipopolysaccharides and lipoproteins $[59,60]$. E.coli is a $\gamma$-protobacteria that belongs to the Entero-bactericeae family and is able to move due to many appendants in the cellular wall. The charge of the cellular wall is negative, and values in the range of $-20 \mathrm{mV}$ to $-60 \mathrm{mV}$ have been reported $[57,58,61]$.

The conditions of our bacteria adhesion assay experiments involve bacteria at the first stage of adhesion where nonspecific interaction between the cell and the surfaces would take place $[62,63]$. The surface charge of unannealed and annealed PEMs measured in HEPES buffer is negative in both cases, being more negative for the annealed PEM than for the unannealed one, with a value of $-31 \pm 3 \mathrm{mV}$ and $-24 \pm 3 \mathrm{mV}$, respectively.

The high hydrophilicity of annealed and unannealed PEMs, assessed by contact angle measurements, reflects a high affinity to water molecules that would confer antifouling properties to these systems used to generate surfaces resistant to bacteria attachment, as has been reported [64]. Our results show a large decrease in bacteria adhesion for both strains in comparison to glass.

Both the increase in the hydrophilicity and the negative charge of the surfaces would contribute to the enhancement of the resistance behavior towards S. aureus bacteria [64]. But the topographic characteristics of the surfaces are also expected to affect the adhesion process. This 
a)
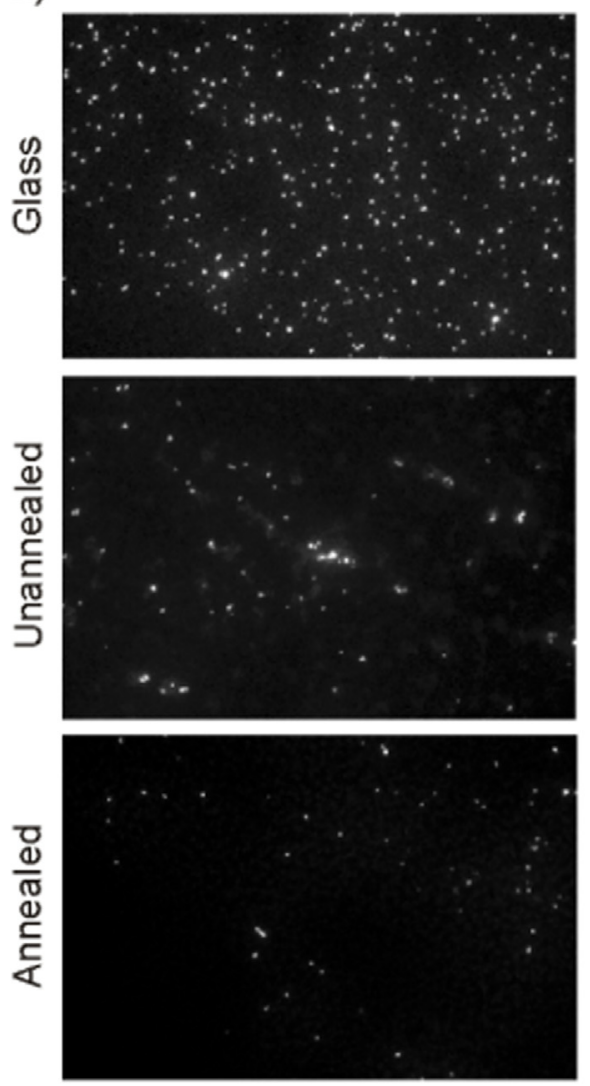

b) 3

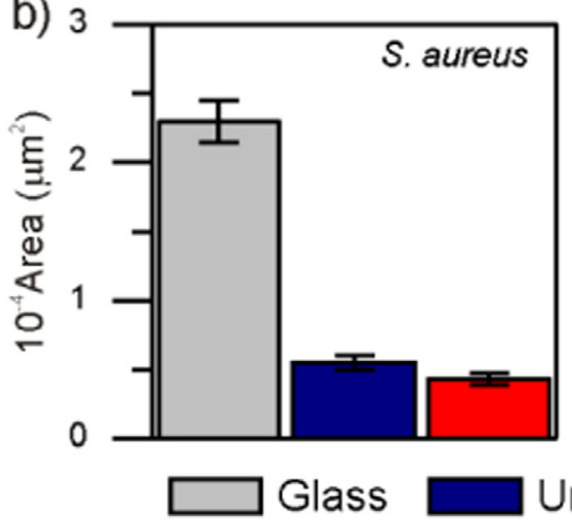

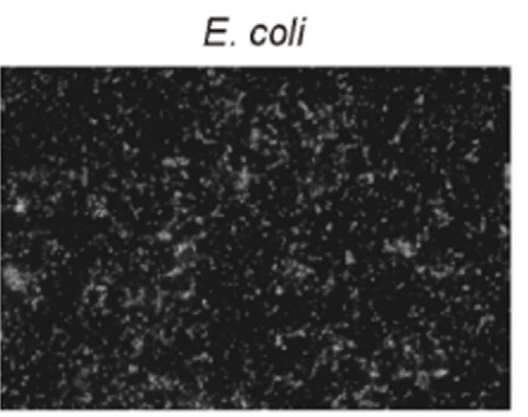
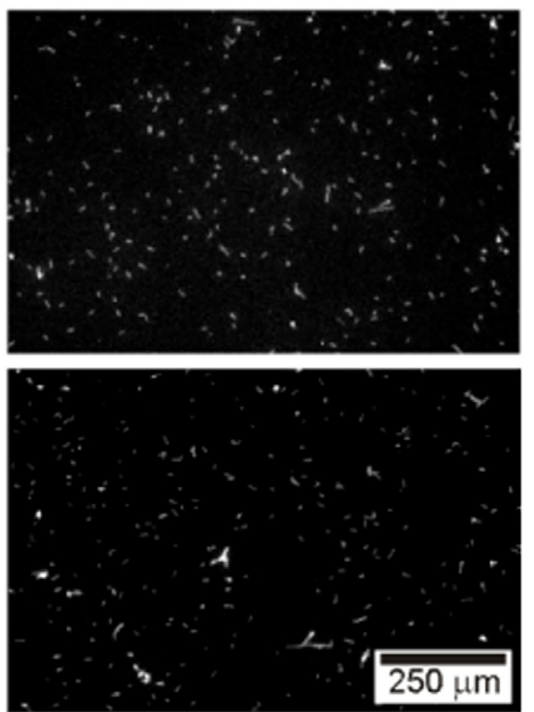

9

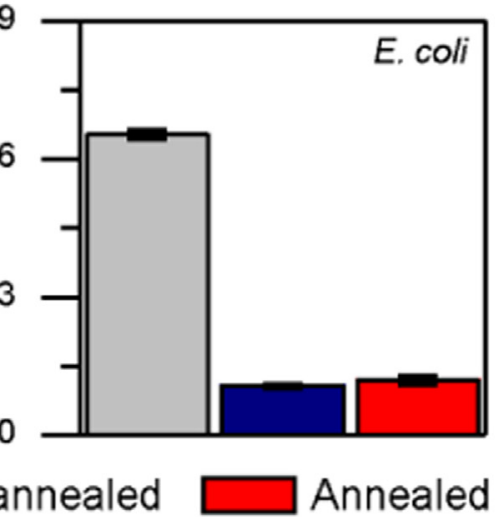

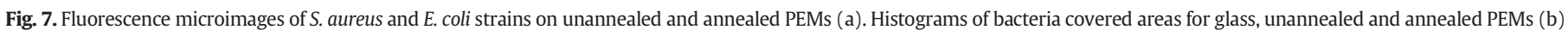
from images shown in (a). Standard errors are included.

aspect has been considered and carefully studied [65-67] Some authors have reported an increase in bacteria adhesion with surface roughness $[68,69]$ while others, the reverse effect $[70,71]$. In these studies the roughness is estimated with the root mean square of heights ( $\mathrm{Rq})$ that can be appropriate for certain surfaces. Other morphological parameters have been used, although not always a clear correlation with adhesion has been reported and deserves more attention and future investigation [72].

From the data profile measured on $5 \times 5$ and $1 \times 1 \mu \mathrm{m}^{2}$ AFM microimages of unannealed and annealed PEMs, the distribution of peaks (Fig. 2e) shows distinct characteristics for unannealed and annealed PEM surfaces. For the latter, a single maximum in the distribution is observed, but for the annealed surface the contribution of at least two populations can be distinguished: one with heights similar to those obtained from the unannealed PEMs, and the other with larger values. These larger peaks exhibit an average separation in the 1-2 $\mu \mathrm{m}$ range, in coincidence with bacteria dimensions. These topographic differences may affect bacteria adhesion by two hypothetical mechanisms: increasing the interaction area between the bacteria and the film surface and generating small holes that restrain $S$. aureus bacteria deposition. The topographic differences described above can affect the adhesion process of $S$. aureus as they are not mobile or possess no adaptable appendants, in contrast to E. coli that adapts better to the change in topography as it has a more complex machinery of fimbriae and flagella associated with the cellular wall $[73,74]$.

\section{Conclusions}

Chitosan/hyaluronic acid multilayers show limited cell adhesion for 4 different mammalian cell lines of different origin and for Gram-positive and Gram-negative bacteria strands. The thermal annealing of the multilayers at $37^{\circ} \mathrm{C}$ for $72 \mathrm{~h}$ results in a more restricted adhesion for 


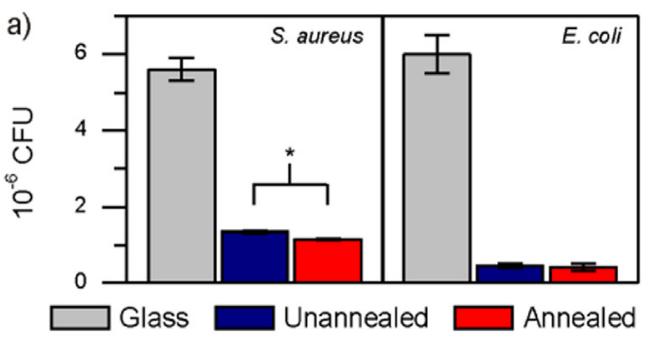

b)

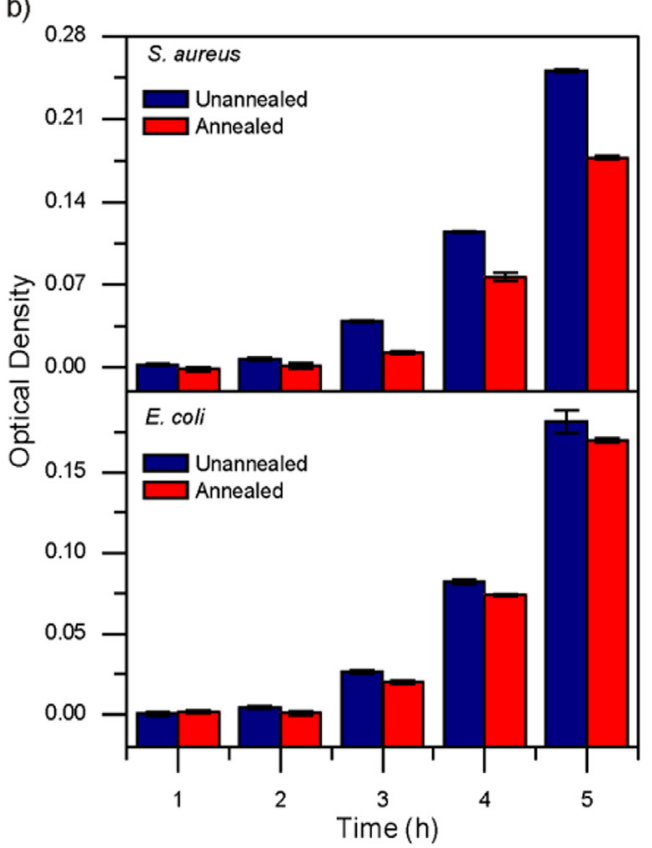

Fig. 8. Colony-forming units (CFU) for S. aureus and E. coli bacteria detached from PEMs used in the adhesion assay (a). Bacteria adhesion quantification by measuring light scattering at $600 \mathrm{~nm}$ and different times (b).

mammalian cells and in a selective $20 \%$ decrease in adhesion of the Gram-positive bacteria, S. aureus.

The enhanced anti-adhesive properties of chitosan/hyaluronic acid PEMs are strongly correlated with the topographic changes produced by the annealing process. The latter retains PEM hydrophilicity, negative surface charge and limited protein adherence, with slight changes in the magnitudes that cannot explain the decrease in cell adherence. On the other hand, PEMs topography is significantly changed due to the annealing. The fibrillar structure is maintained but it gains a more bidimensional appearance, resembling a fractal surface with a more homogeneous surface coverage at the micrometer scale. Furthermore, morphological changes could affect the conformation of the scarce proteins that interact with the PEM surface, modifying cell adhesion behavior.

Regarding bacteria strains, the Gram-positive bacteria, S. aureus, behave differently from E. coli towards the annealed PEM. It can be assumed that for E. coli, the more complex machinery used for active displacement could be adapted to interact with surfaces with different topographic characteristics, while $S$. aureus, a nonmotile organism, may be more affected by PEM topographic features. The average distance between higher peaks on the surface of the unannealed PEM is coincident with the size of $S$. aureus, and an increase in the number of interaction sites and a trapping-like effect could explain the larger adhesion on unannealed PEMs than on annealed ones, the latter with a smoother surface at a size scale close to the bacteria size.

Our results show a simple procedure to generate antifouling coatings based on common biopolymers such as chitosan and hyaluronic acid assembled by means of the layer-by-layer technique and thermally annealed. The procedure has the advantage over other strategies that the coating does not require covalent chemistry but electrostatic interactions and heat, and can be applied to any charged surface.

\section{Acknowledgments}

This work was supported by the European Commission in the framework of FP7 PEOPLE-2009 Project TRASNADE Proposal No. 247656. The authors also acknowledge Consejo Nacional de Investigaciones Científicas y Técnicas (CONICET - Argentina) (Grant No. PIP 0602), Agencia Nacional de Promoción Científica y Tecnológica (ANPCyT - Argentina; PICT-163/08, PICT-2010-2554, PICT-2013-0905), the Austrian Institute of Technology GmbH (AIT-CONICET Partner Group: "Exploratory Research for Advanced Technologies in Supramolecular Materials Science" - Exp. 4947/11, Res. No. 3911, 28-12-2011) and Universidad Nacional de La Plata (UNLP) (11/1129). M.A.P. and O.A. are staff members of CONICET.

\section{Appendix A. Supplementary data}

Supplementary data to this article can be found online at http://dx. doi.org/10.1016/j.msec.2017.07.016.

\section{References}

[1] S. Franz, S. Rammelt, D. Scharnweber, J.C. Simon, Biomaterials 32 (2011) 6692-6709, http://dx.doi.org/10.1016/j.biomaterials.2011.05.078.

[2] S. Veerachamy, T. Yarlagadda, T. Manivasagam, P. Yarlagadda, Proc. Inst. Mech. Eng. H 228 (2014) 1083-1099, http://dx.doi.org/10.1177/0954411914556137.

[3] M. Posaric-Bauden, K. Isaksson, D. Akerberg, R. Andersson, B. Tingstedt, J. Surg. Res. 191 (1) (2014) 196-202, http://dx.doi.org/10.1016/j.jss.2014.04.002.

[4] S. Amornyotin, Endoscopy, Intech, CC BY 3.0 License, 2013http://dx.doi.org/10.5772/ 50355.

[5] V.B. Damodaran, N.S. Murthy, Biomater. Res. 20 (2016) 18, http://dx.doi.org/10. 1186/s40824-016-0064-4.

[6] I. Banerjee, R.C. Pangule, R.S. Kane, Adv. Mater. 23 (2011) 690-718, http://dx.doi. org/10.1002/adma.201001215.

[7] X. Zhao, Y. Su, Y. Li, R. Zhang, J. Zhao, Z. Jiang, J. Membr. Sci. 450 (2014) 111-123, http://dx.doi.org/10.1016/j.memsci.2013.08.044

[8] K. Haraguchi, K. Kubota, T. Takada, S. Mahara, Biomacromolecules 15 (2014) 1992-2003, http://dx.doi.org/10.1021/bm401914c.

[9] H.C. Guo, E. Ye, Z. Li, M.-Y. Han, X.J. Loh, Mater. Sci. Eng. C 70 (2016) 1182-1191, http://dx.doi.org/10.1016/j.msec.2016.01.093.

[10] X. Zhu, X.J. Loh, Biomater. Sci. 3 (2015) 1505-1518, http://dx.doi.org/10.1039/ c5bm00307e.

[11] X.J. Loh, J. Mol. Eng. Mater. 5 (2017) 1740001-1740010, http://dx.doi.org/10.1142/ S2251237317400019.

[12] S. Guo, X. Zhu, X.J. Loh, Mater. Sci. Eng. C 70 (2017) 1163-1175, http://dx.doi.org/10. 1016/j.msec.2016.03.074.

[13] Y.-L. Wu, X. Chen, W. Wang, X.J. Loh, Macromol. Chem. Phys. 217 (2016) 175-188, http://dx.doi.org/10.1002/macp.201500172.

[14] X. Fan, J.Y. Chung, Y.X. Lim, Z. Li, X.J. Loh, Appl. Mater. Interfaces 8 (2016) 33351-33370, http://dx.doi.org/10.1021/acsami.6b09110.

[15] V. Fitzpatrick, L. Fourel, O. Destaing, F. Gilde, C. Albigès-rizo, C. Picart, T. Boudou, Sci Rep 7 (2017) 41479, http://dx.doi.org/10.1038/srep41479.

[16] M. Kumorek, O. Janoušková, A. Höcherl, M. Houska, E. Mázl-chánová, N. Kasoju, L. Cuchalová, R. Matějka, D. Kubies, Appl. Surf. Sci. 411 (2017) 240-250, http://dx. doi.org/10.1016/j.apsusc.2017.03.193.

[17] T. Kruk, K. Szczepanowicz, D. Kregiel, L. Szyk-Warszyńska, P. Warszyński, Colloids Surf. B 137 (2016) 158-166, http://dx.doi.org/10.1016/j.colsurfb.2015.06.016.

[18] S. Schmidt, N. Madaboosi, K. Uhlig, D. Köhler, A. Skirtach, C. Duschl, H. Möhwald, D.V. Volodkin, Langmuir 28 (2012) 7249-7257, http://dx.doi.org/10.1021/ la300635z.

[19] D. Volodkin, A. Skirtach, H. Möhwald, Adv. Polym. Sci. 240 (2010) 135-161, http:// dx.doi.org/10.1007/12_2010_79.

[20] J.M. Mets, J.T. Wilson, W. Cui, E.L. Chaikof, Adv. Healthc. Mater. 2 (2013) 266-270, http://dx.doi.org/10.1002/adhm.201200148.

[21] A. Nishiguchi, H. Yoshida, M. Matsusaki, M. Akashi, Adv. Mater. 23 (2011) 3506-3510, http://dx.doi.org/10.1002/adma.201101787.

[22] J. Borges, M.P. Sousa, G. Cinar, S.G. Caridade, M.O. Guler, J.F. Mano, Adv. Funct. Mater. 27 (1605122) (2017) 1-14, http://dx.doi.org/10.1002/adfm.201605122.

[23] R. Lakshminarayanan, X.J. Loh, S. Gayathri, S. Sindhu, Y. Banerjee, R.M. Kini, S. Valiyaveettil, Biomacromolecules 7 (2006) 3202-3209, http://dx.doi.org/10.1021/ bm0605412.

[24] C. Dhand, N. Dwivedi, X.J. Loh, A.N. Jie Ying, N.K. Verma, R.W. Beuerman, R. Lakshminarayanan, S. Ramakrishna, RSC Adv. 5 (2015) 105003-105037, http://dx doi.org/10.1039/C5RA19388E. 
[25] X.J. Loh, T.-C. Lee, Q. Dou, G.R. Deen, Biomater. Sci. 4 (2016) 70-86, http://dx.doi.org/ $10.1039 / \mathrm{c} 5 \mathrm{bm} 00277 \mathrm{j}$.

[26] Q. Dou, X. Fang, S. Jiang, P.L. Chee, T.-C. Lee, X.J. Loh, RSC Adv. 5 (2015) 46817-46822, http://dx.doi.org/10.1039/C5RA07968C.

[27] Q. Dou, C.P. Teng, E. Ye, X.J. Loh, Int. J. Nanomedicine 10 (2015) 419-432, http://dx. doi.org/10.2147/IJN.S74891.

[28] Z. Li, E. Ye, D.R. Lakshminarayanan, X.J. Loh, Small 12 (2016) 4782-4806, http://dx. doi.org/10.1002/smll.201601129.

[29] E. Ye, M.D. Regulacio, M.S. Bharathi, H. Pan, M. Lin, M. Bosman, K.Y. Win, H. Ramanarayan, S.-Y. Zhang, X.J. Loh, Y.-W. Zhang, M.-Y. Han, Nano 8 (2018) 543-552, http://dx.doi.org/10.1039/C5NR07182H.

[30] B.M. Teo, D.J. Young, X.J. Loh, Part. Part. Syst. Charact. 33 (2016) 709-728, http://dx doi.org/10.1002/ppsc.201600060.

[31] E. Ye, X.J. Loh, Aust. J. Chem. 66 (2013) 997-1007, http://dx.doi.org/10.1071/ CH13168.

[32] D. Rana, T. Matsuura, Chem. Rev. 110 (2010) 2448-2471, http://dx.doi.org/10.1021/ cr800208y.

[33] M. Bulwan, K. Wójcik, S. Zapotoczny, M. Nowakowska, J. Biomater. Sci. Polym. Ed. 23 (2012) 1964-1980, http://dx.doi.org/10.1163/092050611X601711.

[34] G. Decher, J.D. Hong, J. Schmitt, Thin Solid Films 210 (1992) 831-835, http://dx.doi. org/10.1016/0040-6090(92)90417-A.

[35] S.G. Caridade, C. Monge, F. Gilde, T. Boudou, J.F. Mano, C. Picart, Biomacromolecules 14 (2013) 1653-1660, http://dx.doi.org/10.1021/bm400314s.

[36] J. Zhou, G. Romero, E. Rojas, L. Ma, S. Moya, C.J. Gao, Colloid Interface Sci. 345 (2010) 241-247, http://dx.doi.org/10.1016/j.jcis.2010.02.004.

[37] N.E. Muzzio, D. Gregurec, E. Diamanti, J. Irigoyen, M.A. Pasquale, O. Azzaroni, S.E. Moya, Adv. Mater. Interfaces (2016)http://dx.doi.org/10.1002/admi.201600126.

[38] E. Diamanti, N. Muzzio, D. Gregurec, J. Irigoyen, M. Pasquale, O. Azzaroni, M. Brinkmann, S.E. Moya, Colloids Surf. B 145 (2016) 328-337, http://dx.doi.org/10. 1016/j.colsurfb.2016.05.013.

[39] R. Lakshminarayanan, E.O. Chi-Jin, X.J. Loh, R.M. Kini, S. Valiyaveettil, Biomacromolecules 6 (2005) 1429-1437, http://dx doi.org/10.1021/bm049276f.

[40] N. Higashi, K. Yasufuku, Y. Matsuo, T. Matsumoto, T. Koga, Colloids Interface Sci. Commun. 1 (2014) 50-53, http://dx.doi.org/10.1016/j.colcom.2014.07. 002.

[41] S. Grohmann, H. Rothe, K. Liefeith, Biointerphases 7 (2012) 62, http://dx.doi.org/10 1007/s13758-012-0062-6.

[42] A. Lagunas, J. Comelles, E. Martínez, E. Prats-Alfonso, G.A. Acosta, F. Albericio, J. Samitier, Nanomed.: Nanotechnol., Biol. Med. 8 (2012) 432-439, http://dx.doi.org/ 10.1016/j.nano.2011.08.001.

[43] U. Horzum, B. Ozdil, D. Pesen-Okvur, MethodsX 1 (2014) 56-59, http://dx.doi.org/ 10.1016/j.mex.2014.06.004.

[44] B.G. Keselowky, D.M. Collard, A.J. García, J. Biomed. Mater. Res. A 66 (2003) 247-259, http://dx.doi.org/10.1002/jbm.a.10537.

[45] F. Gentile, L. Tirinato, E. Battista, F. Causa, C. Liberale, E.M. di Fabrizio, P. Decuzzi, Biomaterials 31 (2010) 7205-7212, http://dx.doi.org/10.1016/j.biomaterials.2010.06. 016.

[46] A.T. Nguyen, S.R. Sathe, E.K.F. Yim, J. Phys. Condens. Matter 28 (2016) 183001, http://dx.doi.org/10.1088/0953-8984/28/18/183001.

[47] D. Yang, X. Lü, Y. Hong, T. Xi, D. Zhang, Biomaterials 34 (2013) 5747-5758, http://dx doi.org/10.1016/j.biomaterials.2013.04.028.

[48] C.J. Arias, R.L. Surmaitis, J.B. Schlenoff, Langmuir 32 (2016) 5412-5421, http://dx.doi. org/10.1021/acs.langmuir.6b00784.

[49] L. Bačáková, E. Filová, M. Parizek, T. Ruml, V. Švorčík, Biotechnol. Adv. 29 (2011) 739-767, http://dx.doi.org/10.1016/j.biotechadv.2011.06.004.
[50] M.S. Lord, B.G. Cousins, P.J. Doherty, J.M. Whitelock, A. Simmons, R.L. Williams, B.K. Milthorpe, Biomaterials 27 (2006) 4856-4862, http://dx.doi.org/10.1016/j. biomaterials.2006.05.037.

[51] M.B. Hovgaard, K. Rechendorff, J. Chevallier, M. Foss, F. Besenbacher, J. Phys. Chem. B 112 (2008) 8241-8249, http://dx.doi.org/10.1021/jp801103n.

[52] M.S. Lord, M. Foss, F. Besenbacher, Nano Today 5 (2010) 66-78, http://dx.doi.org/10. 1016/j.nantod.2010.01.001.

[53] J. Willey, L. Sherwood, C.J. Woolverton, Prescott's Microbiology $9^{\text {th }}$ Edition, McGrawHill, New York, 2011.

[54] S. Brown, J.P. Santa Maria, S. Walker, Annu. Rev. Microbiol. 67 (2013) 313-333, http://dx.doi.org/10.1146/annurev-micro-092412-155620.

[55] M.G. Percy, A. Grundling, Annu. Rev. Microbiol. 68 (2014) 81-100, http://dx.doi.org/ 10.1146/annurev-micro-091213-112949.

[56] E. Kłodzińska, M. Szumski, K. Hrynkiewicz, E. Dziubakiewicz, M. Jackowski, M. Buszewski, Electrophoresis 30 (2009) 3086-3091, http://dx.doi.org/10.1002/elps. 200900186.

[57] E. Kłodzińska, M. Szumski, E. Dziubakiewicz, K. Hrynkiewicz, E. Skwarek, W. Janusz, B. Buszewski, Electrophoresis 31 (2010) 1590-1596, http://dx.doi.org/10.1002/elps. 200900559.

[58] N. Mitik-Dineva, J. Wang, V. Khanh Truong, P. Stoddart, F. Malherbe, R.J. Crawford, E.P. Ivanova, Curr. Microbiol. 58 (2009) 268-273, http://dx.doi.org/10.1007/ s00284-008-9320-8.

[59] C. Whitfield, M.S. Trent, Annu. Rev. Biochem. 83 (2014) 99-128, http://dx.doi.org/ 10.1146/annurev-biochem-060713-035600.

[60] S. Okuda, H. Tokuda, Annu. Rev. Microbiol. 65 (2011) 239-259, http://dx.doi.org/10. 1146/annurev-micro-090110-102859.

[61] H. Schwegmann, A.J. Feitz, F.H. Frimmel, J. Colloid Interface Sci. 347 (2010) 43-48, http://dx.doi.org/10.1016/j.jcis.2010.02.028.

[62] Y.H. An, R.J. Friedman, Handbook of Bacterial Adhesion: Principles, Methods, and Applications, Totowa NJ, Humana Press, 2000.

[63] D. Campoccia, L. Montanaro, C.R. Arciola, Biomaterials 34 (2013) 8533-8554, http:// dx.doi.org/10.1016/j.biomaterials.2013.07.089.

[64] G.-A. Junter, P. Thébault, L. Lebrun, Acta Biomater. 30 (2016) 13-25, http://dx.doi. org/10.1016/j.actbio.2015.11.010.

[65] F. Song, H. Koo, D. Ren, J. Dent. Res. 94 (2015) 1027-1034, http://dx.doi.org/10. $1177 / 0022034515587690$

[66] H.H. Tuson, D.B. Weibel, Soft Matter 9 (2013) 4368-4380, http://dx.doi.org/10. 1039/c3sm27705d.

[67] L.C. Hsu, J. Fang, D.A. Borca-Tasciuc, R.W. Worobo, C.I. Moraru, Appl. Environ. Microbiol. 79 (2013) 2703-2712, http://dx.doi.org/10.1128/AEM.03436-12.

[68] L. Liu, B. Ercan, L. Sun, K.S. Ziemer, T.J. Webster, ACS Biomater Sci. Eng. 2 (2016) 122-130, http://dx.doi.org/10.1021/acsbiomaterials.5b00431.

[69] C. Lüdecke, M. Roth, W. Yu, U. Horn, J. Bossert, K.D. Jandt, Colloids Surf. B 145 (2016) 617-625, http://dx.doi.org/10.1016/j.colsurfb.2016.05.049.

[70] M.R. Park, M.K. Banks, B. Applegate, T.J. Webster, Int. J. Nanomedicine 3 (2008) 497-504, http://dx.doi.org/10.2147/IJN.S4399.

[71] N. Mitik-Dineva, J. Wang, V.K. Truong, P.R. Stoddart, F. Malherbe, R.J. Crawford, E.P. Ivanova, Biofouling 25 (2009) 621-631, http://dx.doi.org/10. 1080/08927010903012773.

[72] M. Lorenzetti, I. Dogša, T. Stošicki, D. Stopar, M. Kalin, S. Kobe, S. Novak, ACS Appl. Mater. Interfaces 7 (2015) 1644-1651, http://dx.doi.org/10.1021/am507148n.

[73] L. Rizzello, A. Galeone, G. Vecchio, V. Brunetti, S. Sabella, P.P. Pompa, Nanoscale Res. Lett. 7 (2012) 575, http://dx.doi.org/10.1186/1556-276X-7-575.

[74] L. Rizzello, B. Sorce, S. Sabella, G. Vecchio, A. Galeone, V. Brunetti, R. Cingolani, P.P. Pompa, ACS Nano 5 (2011) 1865-1876, http://dx.doi.org/10.1021/nn102692m. 